\title{
Improvement of the Accuracy of Hepatitis B Surface Antigen Testing Using a Confirmatory Test
}

\author{
Hee Jin Huh ${ }^{1}$, Sholhui Park ${ }^{2 \oplus}$, Jungwon Huh ${ }^{2 \oplus}$, Miae Lee ${ }^{2 \oplus}$, and Soo-Kyung Kim ${ }^{2 \oplus}$ \\ ${ }_{1}^{1}$ Department of Laboratory Medicine, Dongguk University Ilsan Hospital, Goyang; 2Department of Laboratory Medicine, Ewha \\ Womans University College of Medicine, Seoul, Korea
}

\section{Corresponding author:}

Soo-Kyung Kim

Department of Laboratory Medicine, Ewha Womans University College of Medicine, 1071 Anyangcheon-ro, Yangcheon-gu, Seoul 07985, Korea Tel +82-2-2650-5043

E-mail skkim1@ewha.ac.kr

Received: February 5, 2021

Revised: April 14, 2021

Accepted: April 28, 2021
This is an Open Access article distributed under the terms of the Creative Commons Attribution Non-Commercial License (http://creativecommons.org/licenses/ by-nc/4.0) which permits unrestricted non-commercial use, distribution, and reproduction in any medium, provided the original work is properly cited.
Background: The hepatitis B surface antigen ( $\mathrm{HBsAg}$ ) is one of the most important serologic markers in diagnosing hepatitis $B$ virus infection. As more sensitive immunoassays become available, the false positive rate of HBsAg has been increasing. Therefore, it has been suggested that a standardized HBsAg testing strategy be implemented to maximize the accuracy and minimize cost and complexity. This study evaluated HBsAg confirmatory tests and the HBsAg testing process to reduce false-positive HBsAg results, and the financial and time burden of the laboratory.

Methods: Samples with Elecsys HBsAg II (Roche Diagnostics, Germany) cutoff index (COI) 0.9-50.0 and Alinity i HBsAg (Abbott, Ireland) signal-to-cutoff (S/CO) 1.0-30.0 were analyzed with the Elecsys HBsAg confirmatory test (Roche Diagnostics) and the Alinity i HBsAg qualitative II confirmatory test (Abbott), respectively.

Results: The Elecsys and Alinity confirmatory tests were positive in $94.0 \%$ $(47 / 50)$ and $69.4 \%(25 / 36)$ of tested samples, respectively. HBsAg COI results were significantly higher in the confirmatory test positive group than the confirmatory test negative group (Elecsys HBsAg median COI 1.20 vs. 4.38 $[P=0.024]$ and Alinity HBsAg median $\mathrm{S} / \mathrm{CO} 1.36$ vs. $4.65[P=0.000])$. HBsAg test specificity was $100 \%$ with Elecsys COI 1.3 and Alinity S/CO 2.9.

Conclusions: The HBsAg value which is likely to be positive in the neutralization test, differed depending on the patient population and reagents. By performing a neutralization test for weakly positive samples below the cutoff and adapting a single serological test strategy for samples above the cutoff, we expected to decrease false-positive results, with less time and effort.

(Lab Med Qual Assur 2021;43:80-86)

Key Words Hepatitis B surface antigen, Confirmatory test, Neutralization test
서론

혈청학적 검사는 바이러스 감염의 선별검사로 널리 사용되 며 핵산검사보다 저렴하다는 장점이 있다. B형간염표면항원 (hepatitis B surface antigen, $\mathrm{HBsAg}$ )은 B형간염바이러스 감염
시 가장 먼저 나타나는 혈청학적 표지자로 $\mathrm{B}$ 형간염바이러스 감염 진단에 중요하게 사용되나 최근 더욱 민감한 면역검사법들이 도입 되면서 위양성률이 증가하고 있다.

검사과정을 단순화하면서도 검사의 정확성을 향상시키기 위해 World Health Organization (WHO)에서는 검사실마다 표준화 
된 $\mathrm{HBsAg}$ 검사전략을 도입할 것을 권고하고 있으며, 단일 혈청학 적 검사전략(one-assay serological testing strategy)과 이중 혈청학적 검사전략(two-assay serological testing strategy)을 제시하고 있다[1]. 단일 혈청학적 검사전략은 한 가지 혈청학적 검 사방법만 사용하여 $\mathrm{HBsAg}$ 검사결과를 보고하는 빠르고 경제적인 방법이나, 위양성 결과가 보고될 수 있다. 이중 혈청학적 검사전략 은 서로 다른 종류의 혈청학적 검사를 연속적으로 사용하는 방법 으로, 첫번째 혈청학적 검사결과 양성이 나온 경우 유사한 민감도 의 다른 혈청학적 검사 또는 중화검사를 통해 확인 후 보고하는 방 법이다. 이중 혈청학적 검사전략은 검사의 양성예측도를 향상시킬 수 있으나 일선 검사실에서 모든 양성 검체를 다른 검사법으로 확 인하기에는 비용과 시간 부담이 크다.

저자들은 $\mathrm{HBsAg}$ 검사의 정확도를 향상시키면서도 효율적으로 운영할 수 있는 검사 프로세스를 도입하고자 하였으며, 이에 중화 검사를 적용해야 하는 $\mathrm{HBsAg}$ 검사의 컷오프를 설정하고자 하였다.

\section{재료 및 방법}

2020년 1월부터 2020년 11월까지 이대목동병원 진단검사의 학과에 HBsAg 검사가 의뢰되고, Roche Cobas e801 analyzer 를 이용한 Elecsys HBsAg II (Roche Diagnostics, Mannheim, Germany) 검사결과가 0.9-50.0 cutoff index (COI)에 해당하 는 검체를 대상으로 Elecsys HBsAg confirmatory test (Roche Diagnostics)를 시행하였다. Elecsys HBsAg II는 전기화학발광 면역분석(electrochemiluminescence immunoassay) 원리 를 이용하여 $\mathrm{HBsAg}$ 을 정성적으로 검출한다. 검체 내의 $\mathrm{HBsAg}$ 은 시약 내 비오틴화된 anti-HBs, 루테늄(ruthenium)으로 표 지된 anti-HBs와 샌드위치 복합체를 형성한다. 이후 스트렙타 비딘(streptavidin)이 코팅된 미세입자가 추가되고, 이 복합체 는 비오틴-스트렙타비딘 상호작용을 통해 고체상에 결합한다. 이후 전극에 전압을 가해 화학발광반응을 유도하고, 광증폭기 (photomultiplier)로 측정한 결과를 소프트웨어를 통해 COI로 변 환한다. COI 결과가 0.9 미만인 경우 음성, 0.9 이상 1.0 미만인 경 우 경계값, 1.0 이상인 경우 양성으로 판정한다. 제조사에서는 초 회 양성으로 결과가 나온 검체에 대해 반복검사를 시행하고, 반복 검사에서도 양성인 경우 중화검사를 시행할 것을 권고하고 있다.

Elecsys HBsAg 중화검사는 환자 검체를 중화시약(anti-HBs $>200,000 \mathrm{IU} / \mathrm{L}$ )과 컨트롤시약(anti-HBs <3 IU/L)으로 각각 전 처리한 후 $\mathrm{HBsAg}$ 검사를 시행하여, 각각의 $\mathrm{CO}$ 를 구하고 이를 비 교한다. 즉 컨트롤시약으로 전처리한 $\mathrm{CO}$ 를 $100 \%$ 라고 하였을 때, 중화시약으로 전처리한 검체의 $\mathrm{COI}$ 를 $\mathrm{X} \%$ 로 계산한다. $\mathrm{X} \leq 60 \%$ 이며 컨트롤시약 $\mathrm{COI} \geq 0.81$ 인 경우 $\mathrm{HBsAg}$ 양성으로 판정한
다. $X>60 \%$ 이며 컨트롤시약 $\mathrm{COI} \geq 0.81$ 인 경우 음성으로 판정 한다. $X \leq 60 \%$ 이며 컨트롤시약 $\mathrm{COI}<0.81$ 인 경우에는 미결정 (indeterminate), $X>60 \%$ 이며 컨트롤 시약 $\mathrm{COI}<0.81$ 인 경우는 무효(invalid)로 재검이 필요하다.

동일한 기간에 동국대학교 일산병원에서 Alinity i (Abbott, Sligo, Ireland) 장비와 HBsAg Qualitative II Reagent Kit (Abbott)을 사용한 검사결과가 1.0-30.0 signal-to-cutoff (S/CO) 범위인 검체를 대상으로 HBsAg Qualitative II Confirmatory Reagent Kit (Abbott)를 사용하여 중화검사를 시 행하였다. Alinity HBsAg Qualitative II는 화학발광면역검사 (chemiluminescence immunoassay)로 $\mathrm{HBsAg}$ 을 정성적으 로 검출한다. 검체와 anti-HBs가 부착된 미세입자, 아크리디늄 (acridinium)이 표지된 anti-HBs 접합체(conjugate)가 반응하 여 복합체를 형성하고, 세척 단계를 거친 후 pre-trigger, trigger 시약이 추가되고 화학발광반응이 측정된다. Alinity HBsAg 검사 의 컷오프는 $1.0 \mathrm{~S} / \mathrm{CO}$ 로, $\mathrm{S} / \mathrm{CO}$ 가 1.00 미만인 검체는 음성, 1.00 이상인 경우 양성으로 판정한다. 제조사 지침상 양성인 경우 반복 검사를 시행하고, 반복검사에서도 양성인 경우 중화검사를 권고하 고 있다.

Alinity HBsAg 중화검사는 검체를 pretreatment 1 (anti$\mathrm{HBs}$ 포함)과 pretreatment 2 (anti-HBs 불포함) 시약으로 각 각 전처리한 후 $\mathrm{HBsAg}$ 검사를 시행하여 장비에서 자동적으로 $\%$ Neutralization을 계산한다. \%Neutralization $\geq 50 \%$ 이고, pretreatment 2로 전처리한 검체의 $\mathrm{S} / \mathrm{CO}$ (HBsAgQuaC2)가 0.70 이상인 경우 양성 판정한다. $\mathrm{HBsAgQuaC2} \mathrm{S} / \mathrm{CO}$ 가 0.70 미 만이거나, \%Neutralization $<50 \%$ 이면서 HBsAgQuaC2 S/CO 가 10.00 미만인 경우는 미확인(not confirmed)으로 $\mathrm{HBsAg}$ 이 외의 다른 혈청학적 표지자를 이용한 추가검사 또는 4 주에서 6 주 뒤에 재검할 것을 권장한다.

대상 검체의 B형간염바이러스 혈청학적 표지자(anti-HBs, hepatitis $B$ e antibody [anti-HBe], hepatitis $B$ e antigen [HBeAg], hepatitis $B$ core antigen [anti-HBc] total, anti$\mathrm{HBC}$ immunoglobulin M) 및 B형간염바이러스 DNA 검사결과 와 대상 환자의 $\mathrm{B}$ 형간염바이러스 백신 접종력, $\mathrm{B}$ 형간염 과거력 및 치료력을 수집하였다.

두 집단 간의 범주형 자료는 Pearson's chi-square 검정을 이 용하여 비교하였다. 두 집단 간의 연속변수는 Mann-Whitney 검 정을 이용하여 비교하였다. $\mathrm{HBsAg}$ 중화검사를 기준으로 $\mathrm{HBsAg}$ $\mathrm{CO}$ 에 따른 민감도와 특이도를 평가하고, 적절한 컷오프를 구하 기 위해 receiver operating characteristic (ROC) 곡선 분석을 시행하였다. 통계분석을 위해 Microsoft Excel 2016 (Microsoft Corp., Redmond, WA, USA)과 IBM SPSS Statistics for 
Windows ver. 19.0 (IBM Corp., Armonk, NY, USA)을 사용하 였다. 본 연구는 이대목동병원과 동국대학교일산병원 임상연구심 의위원회의 승인을 받았다(승인번호: EUMC 2020-01-011, DUIH 2020-01-014-001).

\section{결과}

검사대상의 임상적 특징은 Table 1 과 같다. 연구기간에 이 대목동병원에서 시행된 $\mathrm{HBsAg}$ 검사 건수는 총 15,466 건이었 다. 이 중 반복검사 결과 $0.9 \mathrm{COI}$ 이상인 검체는 537건이었다. 0.9-50.0 COI에 해당하는 검체는 총 59개였으며, 검체량이 부족 한 환자 및 한 환자가 여러 검사일에 중복검사한 경우를 제외하 고, 총 50 개 검체를 대상으로 Roche Elecsys HBsAg 중화검사 를 시행하였다. 이 중 $94.0 \%$ (47/50)는 중화검사상 양성으로 판 정되었으나, $6.0 \%$ (3/50)는 중화검사 결과 최종 음성으로 판정 되었다. Elecsys $\mathrm{HBsAg}$ 중화검사 결과 양성으로 판정된 검체의

Table 1. Clinical characteristics of study participants

\begin{tabular}{lccc}
\hline & $\begin{array}{c}\text { Elecsys } \\
(\mathrm{n}=50)\end{array}$ & $\begin{array}{c}\text { Alinity } \\
(\mathrm{n}=36)\end{array}$ & $P$-value \\
\hline Age (yr) & $62.6 \pm 11.7$ & $55.5 \pm 16.5$ & 0.031 \\
Sex (male:female) & $32: 18$ & $24: 12$ & 0.798 \\
Previous HBV history & & & 0.011 \\
Yes (\%) & $37(74)$ & $17(47)$ & \\
No (\%) & $13(26)$ & $19(53)$ & \\
\hline
\end{tabular}

Values are presented as mean \pm standard deviation or number (\%). Abbreviation: HBV, hepatitis B virus.

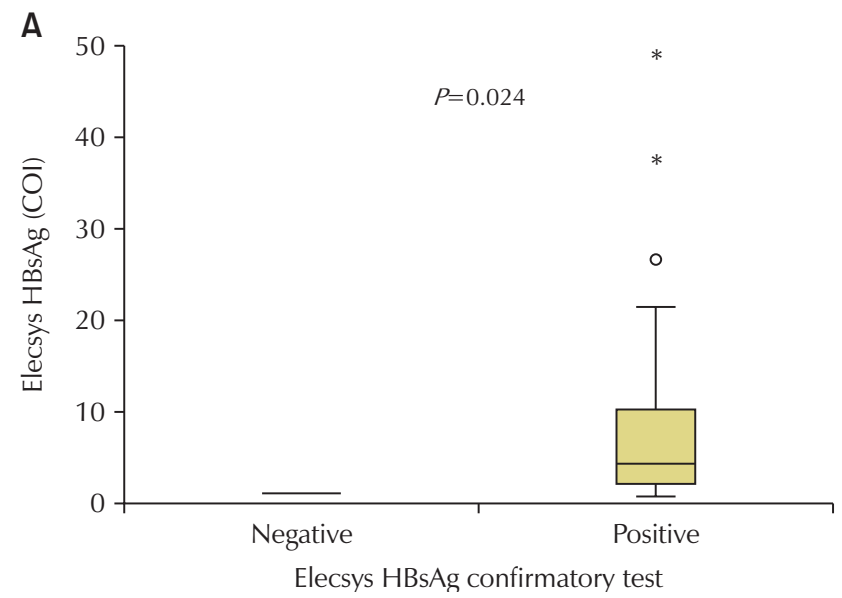

HBsAg 정중 COI는 4.38 (25\%-75\% interquartile range [IQR], 2.21-10.70)로 음성으로 판정된 검체의 $\mathrm{HBsAg}$ 정중 $\mathrm{COI} 1.20$ (IQR, 1.10-1.20)보다 유의하게 높았다 $(P=0.024)$. 중화검사 결과 를 바탕으로 Elecsys HBsAg 검사의 ROC 분석을 시행한 결과 곡 선하면적(area under the curve, AUC)은 0.876 이었다(Fig. 1). Elecsys HBsAg 1.3 COI를 컷오프로 설정하는 경우 민감도 $85 \%$, 특이도 $100 \%$ 로 중화검사 결과를 예측할 수 있었다. Elecsys $\mathrm{HBsAg} 6.0 \mathrm{CO}$ 를 컷오프로 설정하는 경우 민감도 $36 \%$, 특이도 $100 \%$ 로 중화검사 결과를 예측할 수 있었다. Elecsys HBsAg 검 사결과 양성이었으나 중화검사상 음성으로 최종 판정된 환자들의 $\mathrm{B}$ 형간염바이러스 혈청학적 표지자는 Table 2 와 같다.

연구기간에 동국대학교일산병원에서 시행된 $\mathrm{HBsAg}$ 검사 건수 는 총 21,882 건이었다. 이 중 반복검사 결과 $1.0 \mathrm{~S} / \mathrm{CO}$ 이상으로 양성 보고된 건수는 832건이었다. 양성 보고된 검체 중 1.0-30.0 $\mathrm{S} / \mathrm{CO}$ 에 해당하는 검체는 총 52 개였으며, 검체량이 부족한 환자 및 한 환자가 여러 검사일에 중복검사한 경우를 제외하고, 총 36 개 검체를 대상으로 Abbott Alinity HBsAg 중화검사를 시행하였다. 중화검사를 시행한 36 개 검체 중 $69.4 \%$ (25/36)의 검체가 중화검 사상 양성으로 판정되었다. Alinity HBsAg 중화검사 결과 양성으 로 판정된 검체의 $\mathrm{HBsAg}$ 정중 $\mathrm{S} / \mathrm{CO}$ 는 4.65 (IQR, 2.89-9.86)로 중화반응을 보이지 않은 검체의 $\mathrm{HBsAg}$ 정중 $\mathrm{S} / \mathrm{CO}$ 인 1.36 (IQR, $1.08-2.58)$ 과 유의한 차이를 보였다 $(P=0.000)$. 중화검사 결과를 바탕으로 Alinity HBsAg 검사의 ROC 분석을 시행한 결과 $\mathrm{AUC}$ 는 0.893이었다(Fig. 2). Alinity HBsAg $2.9 \mathrm{~S} / \mathrm{CO}$ 를 컷오프로 하였 을 때, 민감도 $76 \%$, 특이도 $100 \%$ 로 중화검사 결과와 일치하였다. Alinity HBsAg 검사결과 양성이었으나 추가적인 중화검사에서 양 성으로 확진되지 않은 환자들의 특징은 Table 3과 같다.

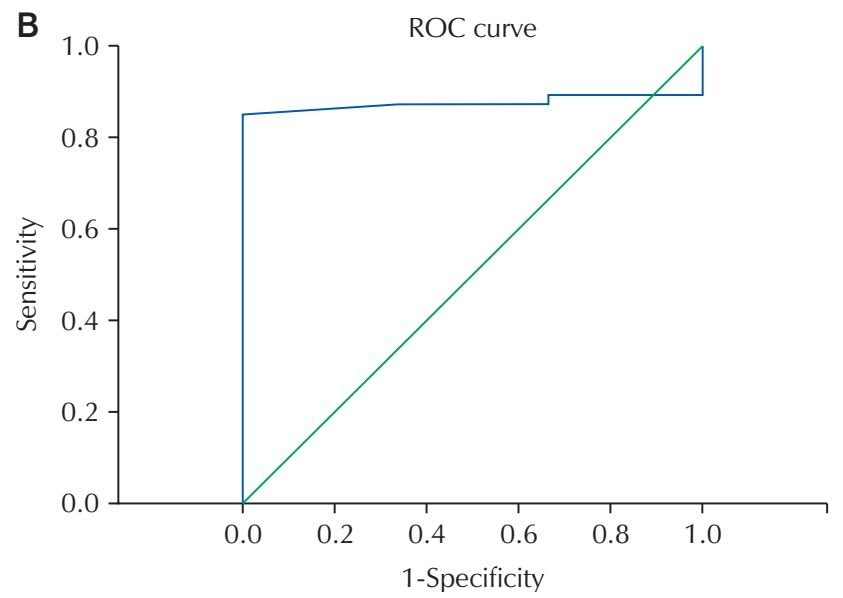

Fig. 1. Elecsys hepatitis B surface antigen (HBsAg) confirmatory test. (A) Box plot of HBsAg cut-off index (COI) based on HBsAg confirmatory test result. The HBsAg COI of HBsAg confirmatory test positive group and negative group showed significant difference. (B) Receiver operating characteristic (ROC) curve analysis of HBsAg based on HBsAg confirmatory test showed area under curve 0.876. 
Table 2. Characteristics of patients initially HBsAg positive but not confirmed with the Elecsys HBsAg confirmatory test

\begin{tabular}{ccccccccc}
\hline Patient no. & Age $(\mathrm{yr})$ & $\mathrm{HBsAg}(\mathrm{COI})$ & Anti-HBs & Anti-HBe & HBeAg & Anti-HBc total & Anti-HBc IgM & HBV DNA \\
\hline 1 & 53 & 1.10 & $\mathrm{R}$ & $\mathrm{N}$ & $\mathrm{N}$ & $\mathrm{N}$ & $\mathrm{N}$ & $\mathrm{NT}$ \\
2 & 37 & 1.20 & $\mathrm{R}$ & $\mathrm{N}$ & $\mathrm{N}$ & $\mathrm{N}$ & $\mathrm{N}$ & $\mathrm{NT}$ \\
3 & 35 & 1.22 & $\mathrm{~N}$ & $\mathrm{R}$ & $\mathrm{N}$ & $\mathrm{R}$ & $\mathrm{N}$ & $\mathrm{ND}$ \\
\hline
\end{tabular}

Abbreviations: HBsAg, hepatitis B surface antigen; COI, cut-off index; anti-HBs, hepatitis B surface antibody; anti-HBe, hepatitis B e antibody; HBeAg, hepatitis B e antigen; anti-HBc, hepatitis B core antigen; IgM, immunoglobulin M; HBV, hepatitis B virus; R, reactive; N, nonreactive; NT, not tested; ND, not detected.
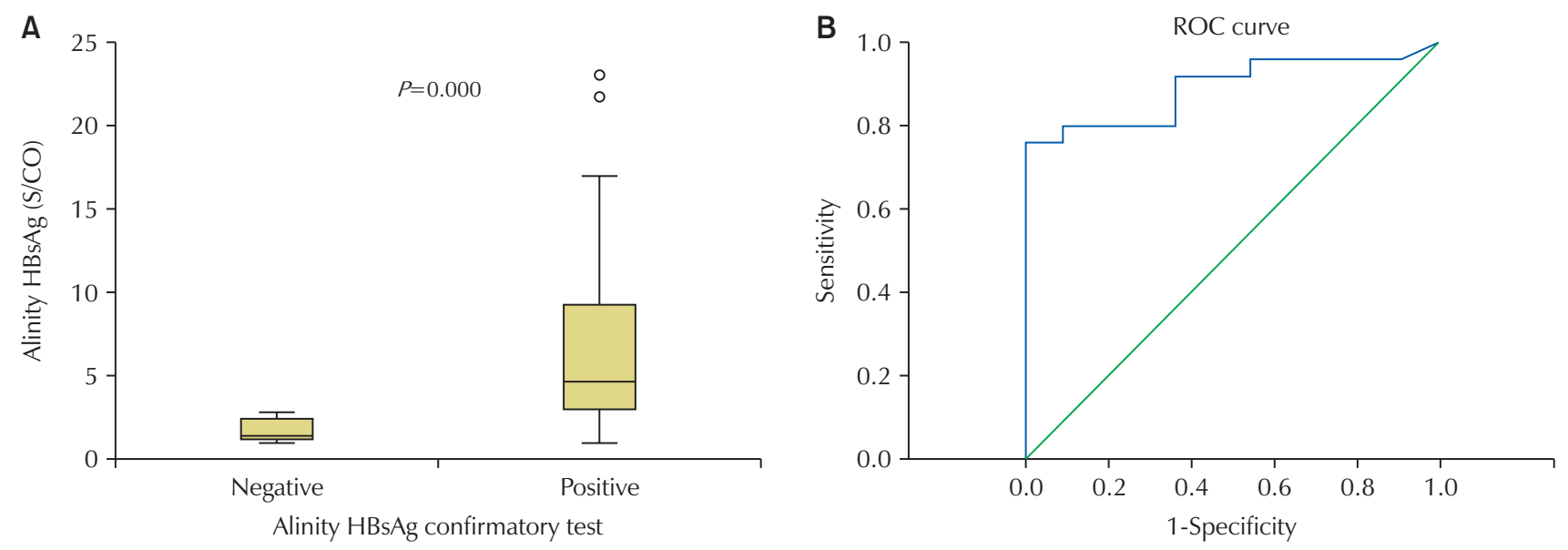

Fig. 2. Alinity hepatitis B surface antigen (HBsAg) confirmatory test. (A) Box plot of HBsAg signal-to-cut-off (S/CO) based on HBsAg confirmatory test result. The $\mathrm{HBsAg} \mathrm{COI}$ of $\mathrm{HBsAg}$ confirmatory test positive group and negative group showed significant difference. (B) Receiver operating characteristic (ROC) curve analysis of HBsAg based on HBsAg confirmatory test showed area under curve 0.893 .

Table 3. Characteristics of patients initially HBsAg positive but not confirmed with the Alinity HBsAg confirmatory test

\begin{tabular}{ccccccccc}
\hline Patient no. & Age $(\mathrm{yr})$ & $\mathrm{HBsAg}(\mathrm{S} / \mathrm{CO})$ & Anti-HBs & Anti-HBe & HBeAg & Anti-HBc total & Anti-HBc IgM & HBV DNA \\
\hline 4 & 22 & 1.05 & $\mathrm{~N}$ & $\mathrm{~N}$ & $\mathrm{~N}$ & $\mathrm{~N}$ & $\mathrm{~N}$ & $\mathrm{~N}$ \\
5 & 60 & 1.08 & $\mathrm{~N}$ & $\mathrm{~N}$ & $\mathrm{~N}$ & $\mathrm{~N}$ & $\mathrm{~N}$ \\
6 & 38 & 2.83 & $\mathrm{~N}$ & $\mathrm{~N}$ & $\mathrm{~N}$ & $\mathrm{~N}$ & $\mathrm{~N}$ & $\mathrm{~N}$ \\
7 & 24 & 1.55 & $\mathrm{R}$ & $\mathrm{N}$ & $\mathrm{N}$ & $\mathrm{N}$ & $\mathrm{N}$ \\
8 & 33 & 1.36 & $\mathrm{R}$ & $\mathrm{N}$ & $\mathrm{N}$ & $\mathrm{R}$ & $\mathrm{N}$ & $\mathrm{N}$ \\
9 & 65 & 2.36 & $\mathrm{R}$ & $\mathrm{N}$ & $\mathrm{N}$ & $\mathrm{N}$ & $\mathrm{N}$ \\
10 & 82 & 1.01 & $\mathrm{R}$ & $\mathrm{R}$ & $\mathrm{N}$ & $\mathrm{R}$ & $\mathrm{N}$ & $\mathrm{NT}$ \\
11 & 51 & 1.27 & $\mathrm{R}$ & $\mathrm{N}$ & $\mathrm{N}$ & $\mathrm{N}$ & $\mathrm{N}$ & $\mathrm{NT}$ \\
12 & 38 & 2.58 & $\mathrm{~N}$ & $\mathrm{~N}$ & $\mathrm{~N}$ & $\mathrm{~N}$ & $\mathrm{~N}$ & $\mathrm{ND}$ \\
13 & 38 & 2.73 & $\mathrm{~N}$ & $\mathrm{~N}$ & $\mathrm{~N}$ & $\mathrm{~N}$ & $\mathrm{~N}$ & $\mathrm{~N}$ \\
14 & 41 & 1.31 & $\mathrm{R}$ & $\mathrm{N}$ & $\mathrm{N}$ & $\mathrm{N}$ & $\mathrm{N}$ \\
\hline
\end{tabular}

Abbreviations: HBsAg, hepatitis B surface antigen; S/CO, signal-to-cut-off; anti-HBs, hepatitis B surface antibody; anti-HBe, hepatitis B e antibody; HBeAg, hepatitis B e antigen; anti-HBc, hepatitis B core antigen; IgM, immunoglobulin M; HBV, hepatitis B virus; N, nonreactive; NT, not tested; ND, not detected; $R$, reactive. 
고찰

$\mathrm{HBsAg}$ 검사의 위양성률을 줄이면서 검사를 효율적으로 운용 하기 위해 WHO에서는 자원이 제한적인 지역이나 HBsAg 혈청학 적 유병률이 $0.4 \%$ 이상인 지역의 경우 단일 혈청학적 검사전략을, $\mathrm{HBsAg}$ 혈청학적 유병률이 $0.4 \%$ 미만인 지역의 경우 이중 혈청학 적 검사전략을 취할 것을 제안하고 있다[1]. 하지만 이러한 제안의 근거는 낮다고 밝히고 있다.

영국의 Public Health England UK Standards for Microbiology Investigations는 초회 $\mathrm{HBsAg}$ 결과가 양성인 경우, 기 존 검사와 유사한 민감도를 갖고 있는 다른 검사법이나 중화검사 를 추가적으로 시행할 것을 권고하고 있다[2]. 호주의 National HBV Testing Policy Expert Reference Committee는 HBsAg 선별검사에서 양성인 경우 제조사의 방침에 따라 중화검사를 통해 확인 검사를 진행할 것을 권장하고 있다[3]. 이와 같이 선진국에서 는 이중 혈청학적 검사전략을 취하고 있으나, 이들 국가의 $\mathrm{HBsAg}$ 혈청학적 유병률은 국내 현황과는 차이가 있다.

한국은 1995년 B형간염바이러스 백신 접종사업이 이루어진 이 후 B형간염바이러스 감염이 상당히 줄었으며, 2010년 기준 성인 인구집단에서의 $\mathrm{HBsAg}$ 혈청학적 유병률은 $3.0 \%$ 인 것에 반해 10 대의 $\mathrm{HBsAg}$ 혈청학적 유병률은 $0.12 \%$ 로 연령 간에 큰 차이를 보 인다[4]. 자동화된 $\mathrm{HBsAg}$ 검사의 민감도와 특이도는 매우 높으 나, 혈청학적 유병률이 낮은 지역에서 많은 검체를 처리하는 과정 에서 위양성 결과가 발생할 수 있다. $1 \%$ 의 유병률을 갖는 지역에 서 특이도가 $99 \%$ 인 검사를 시행한 경우 위양성 결과와 진양성 결 과를 보이는 검체 수는 동일한 반면(양성예측치 $50 \%$ ), 유병률이 $1 \%$ 미만인 지역에서 특이도가 $99 \%$ 인 검사를 시행한 경우 위양 성 결과를 보이는 검체가 진양성 결과를 보이는 검체보다 많아지 게 된다[5].

단일 혈청학적 검사전략은 비록 양성예측도는 낮지만, 검사가 덜 복잡하며 검사 숙련도 유지가 용이하고 적은 비용으로 $\mathrm{HBsAg}$ 양성 환자를 선별할 수 있다는 점에서 공중보건학적인 측면에서는 더 적합할 수 있다[5]. 또한 $\mathrm{HBsAg}$ 검사결과가 위양성으로 나왔 다고 하더라도 B형간염바이러스 DNA, HBsAg 재검 등의 추가검 사를 시행 후 치료방향이 결정되기 때문에 한 번의 위양성 결과가 개인에게 미치는 영향은 크지 않을 수 있다. 이처럼 검사 프로세스 가 각각 가지는 위험과 이익이 있기에 검사실마다 적절한 전략을 취해야 할 것이다.

저자들은 이중 혈청학적 검사전략과 단일 혈청학적 검사전략의 장점을 취하고자 $\mathrm{HBsAg}$ 검사의 $\mathrm{COI}$ 컷오프를 설정하여 위양성률 이 높은 컷오프 미만의 약양성 검체는 중화검사를 시행하고, 컷오 프 이상의 검체는 단일 혈청학적 검사전략을 적용하고자 하였다.
HBsAg 자동화 장비 중 국내에서 가장 많이 사용하고 있는 Roche 사와 Abbott사의 제품을 대상으로 중화검사를 시행하였다.

Elecsys HBsAg 검사에서 0.9-50.0 COI를 보이는 검체 중 $94.0 \%$ 가 중화검사 양성이었으며, Alinity HBsAg 검사에서 $1.0-30.0 \mathrm{~S} / \mathrm{CO}$ 를 보이는 검체 중 $69.4 \%$ 가 중화검사 양성이었 다. 이러한 차이는 검사원리와 시약 조성의 차이 때문일 수 있다. Elecsys HBsAg 검사는 전기화학발광면역분석법으로 마우스와 면양 유래 항체를 이용한다. Alinity HBsAg 검사는 화학발광면역 분석법으로 마우스와 염소 유래 항체를 이용한다. 또한 두 검사의 대상 환자군을 비교해 보았을 때, Elecsys HBsAg 검사를 시행한 환자군의 연령이 유의하게 많고, 신환의 비중은 Alinity HBsAg 검 사를 시행한 환자군에서 유의하게 높았는데, 이러한 대상 환자군의 차이로 인해서도 이러한 차이가 발생할 수 있다. 무엇보다도 두 검 사 모두 정성검사로 두 검사를 시행한 환자의 $\mathrm{HBsAg}$ 농도에 차이 가 존재할 수 있으나, 중화검사 결과 양성으로 확진되지 않은 검체 는 모두 $\mathrm{HBsAg}$ 검사의 컷오프 농도 근처에 분포하였다.

$\mathrm{HBsAg}$ 검사의 AUC는 Elecsys 0.876 , Alinity 0.893 으로 두 검 사시약 모두 좋은 성능을 보였다(Figs. 1, 2). 중화검사에서 양성 으로 확진되지 않은 검체는 약양성 검체에 한정되었으며, Elecsys $\mathrm{HBsAg} 1.3 \mathrm{COI}$ 이상, Alinity HBsAg $2.9 \mathrm{~S} / \mathrm{CO}$ 이상 검체는 중 화검사상 모두 양성으로 확진되었다. Elecsys HBsAg과 중화검 사를 이용한 선행연구에서는 Elecsys $\mathrm{HBsAg} 6.0 \mathrm{CO}$ 이상의 검 체에서 $\mathrm{HBsAg}$ 중화검사가 모두 양성을 보인 바 있는데, 이렇게 두 연구에서 중화검사가 모두 양성을 나타내는 $\mathrm{COI}$ 컷오프에 차 이가 나타난 이유는 대상 환자의 차이 때문일 수 있다[6]. 선행연 구는 Elecsys HBsAg 양성인 신환 136명을 대상으로 하였으며, 이 연구는 HBsAg 양성인 신환 13 명과 구환 37 명을 대상으로 하 였다. 따라서 이번 연구의 HBsAg 진양성 비율이 선행연구에 비해 높을 것으로 생각된다. 중국에서 발표된 연구에 따르면 Elecsys $\mathrm{HBsAg} 4.0 \mathrm{COI}$ 이상의 검체에서 중화검사가 모두 양성이었으며, AUC가 0.933이라는 보고가 있었다[7]. 이 차이는 혈청학적 유병 률 차이 때문으로 생각된다. 중국의 $\mathrm{HBsAg}$ 유병률은 $7.2 \%$ 인 반 면, 한국의 HBsAg 유병률은 $2.98 \%$ 이다[4,8]. Alinity 중화검사는 보고된 선행연구가 없고, 본 연구에 포함된 검체 수가 제한적이나 $2.9 \mathrm{~S} / \mathrm{CO}$ 이상의 검체는 모두 중화검사상 양성 확진되었다.

본 연구를 통해 대상 환자군의 특징, 사용하는 검사시약에 따라 중화검사상 양성으로 확진될 가능성이 높은 $\mathrm{HBsAg}$ 값에 차이가 있음을 확인하였다. 따라서 각 검사실에서 검사시약, 대상 환자군 등의 특징에 따라 평가를 진행하는 것이 도움이 될 것으로 생각한 다. 최소한의 중화검사를 시행하고자 하는 검사실의 경우 $\mathrm{HBsAg}$ 중화검사를 기준으로 특이도 $100 \%$ 를 보이는 가장 낮은 $\mathrm{HBsAg}$ $\mathrm{CO}$ 를 컷오프로 적용할 수 있을 것이다. 중화검사를 어느 정도 시 
행할 수 있는 여건이 되고, 최대한 많은 $\mathrm{HBsAg}$ 위양성 결과를 줄 이는 것을 목표로 하는 검사실의 경우 위 기준보다 높은 $\mathrm{CO}$ 를 컷 오프를 설정하여 조금 더 넓은 농도범위의 검체를 대상으로 중화 검사를 시행할 수 있을 것이다. 본원에서는 위 결과를 바탕으로 Elecsys HBsAg $6.0 \mathrm{COI}$ 이하의 초회 양성 검체를 중화검사 대상 으로 설정하였다. 연구기간 동안 Elecsys $\mathrm{HBsAg}$ 검사를 시행한 환자 중 과거 원내 검사결과가 없거나 음성이고, 이번 $\mathrm{HBsAg}$ 검 사결과가 반복하여 $0.9 \mathrm{COI}$ 이상을 보인 환자는 총 270 명이었다. 이 중 $\mathrm{HBsAg}$ 결과가 $6.0 \mathrm{COI}$ 이하인 환자는 14 명, $1.3 \mathrm{CO}$ 이하 인 환자는 3 명이었다. Elecsys HBsAg과 Alinity HBsAg 중화시험 은 약 1 시간 내지 1 시간 30 분 정도의 시간이 소요되는데, 컷오프 이하 검체만 중화검사를 시행함으로써 시간, 비용 측면에서 더 효 율적으로 운용할 수 있게 되었다.

$\mathrm{HBsAg}$ 검사와 중화검사에 차이를 보인 patient 1 과 2는 B형간 염바이러스 감염력이 없는 환자들로 추정된다(Table 2). Patient 3은 anti-HBe 항체와 anti-HBc 항체가 양성이며, B형간염바이러 스 DNA가 검출되지 않는 환자로, aspartate aminotransferase (AST), alanine aminotransferase (ALT)는 각각 AST $16 \mathrm{IU} / \mathrm{L}$, ALT $9 \mathrm{IU} / \mathrm{L}$ 로 정상치를 보였다. 이 환자는 과거 감염력이 있으나 anti-HBs 항체, B형간염바이러스 DNA가 검출되지 않는 상태로, 감염 후 회복된 상태 또는 잠재감염 환자로 생각된다. Patient 4, $5,6,7,9,11,12,13,14$ 는 B형간염바이러스 감염력이 없는 환자 들로 추정된다(Table 3). Patient 8, 10은 B형간염바이러스 과거 감염력이 있으나 현재 anti-HBs 항체가 생성되었으며 B형간염바 이러스에 면역력이 생성된 환자로 생각된다. $\mathrm{HBsAg}$ 위양성 결과 는 다른 병원체에 대한 항체와의 교차반응, 예방접종, 자가항체 등 다양한 원인에 의해 발생할 수 있는 것으로 알려져 있으나, 본 연
구에서 위양성을 나타낸 검체들에서 이와 같은 원인을 확인할 수 는 없었다[9-11].

본 연구의 한계는 제한된 수의 검체만을 대상으로 하였다는 점 이다. 좀 더 많은 검체를 이용한 추가적인 연구가 필요할 것으로 생각된다. 또한 이대목동병원과 동국대학교일산병원에서 각각의 검체를 이용하여 평가하였기에 Elecsys와 Alinity, 두 HBsAg 중 화시험 간의 비교 평가는 시행하지 못하였다.

저자들은 이 연구에서 $\mathrm{HBsAg}$ 중화검사가 필요한 컷오프를 설 정하여, 위양성률이 높은 약양성 검체는 중화검사를 시행하고, 위 양성 결과를 보이지 않은 컷오프 이상의 검체에 대해서는 단일 혈 청학적 검사전략을 취하고자 하였다. 이를 통해 약양성 검체의 위 양성률을 줄이면서도 대부분의 검체에 대해 빠르고 효율적인 보고 가 가능할 것으로 기대한다.

\section{감사의 글}

이 연구는 대한임상검사정도관리협회 2020년 학술연구비 지원 에 의해 수행되었다(2020-09).

\section{ORCID}

Hee Jin Huh $\quad$ https://orcid.org/0000-0001-6587-8568 Sholhui Park https://orcid.org/0000-0002-6467-427X Jungwon Huh https://orcid.org/0000-0001-8758-9847 Miae Lee Soo-Kyung Kim https://orcid.org/0000-0001-9140-3814 https://orcid.org/0000-0001-9406-8628

\section{REFERENCES}

1. World Health Organization. WHO guidelines on hepatitis B and C testing. http://apps.who.int/iris/bitstre am/10665/254621/1/9789241549981-eng.pdf?ua=1 (Accessed April 14, 2021).

2. Public Health England. UK SMI V 4: investigation of hepatitis B infection. https://www.gov.uk/government/ publications/smi-v-4-hepatitis-b-diagnostic-serology-in-the-immunocompetent-including-hepatitis-b-in-pregnancy (Accessed April 14, 2021).

3. Commonwealth of Australia. National hepatitis B testing policy 2020. http://testingportal.ashm.org.au/files/ASHM_ TestingPolicy_2020_HepatitisB_07_2.pdf (Accessed April 14, 2021).

4. Kim H, Shin AR, Chung HH, Kim MK, Lee JS, Shim JJ, et al. Recent trends in hepatitis B virus infection in the general Korean population. Korean J Intern Med 2013;28:413-9.

5. Parry JV, Easterbrook P, Sands AR. One or two serological assay testing strategy for diagnosis of HBV and HCV infection?: the use of predictive modelling. BMC Infect Dis 2017;17(Suppl 1):705.

6. Kim SK, Huh J, Jeong TD. Proposal of efficient workflows for confirmatory neutralization test for initial hepatitis B 
surface antigen positive samples. Clin Lab 2019;65:1971-4.

7. Shao H, Li Y, Xu WZ, Zhou X. Increased need for testing to confirm initial weakly reactive results for hepatitis B virus surface antigen. Lab Med 2012;43:15-7.

8. Yan YP, Su HX, Ji ZH, Shao ZJ, Pu ZS. Epidemiology of hepatitis B virus infection in China: current status and challenges. J Clin Transl Hepatol 2014;2:15-22.

9. Rysgaard CD, Morris CS, Drees D, Bebber T, Davis SR, Kulhavy J, et al. Positive hepatitis B surface antigen tests due to recent vaccination: a persistent problem. BMC Clin Pathol 2012;12:15.

10. Warren K, Eastlund T. False-reactive test for hepatitis B surface antigen following administration of granulocytecolony-stimulating factor. Vox Sang 2002;83:247-9.

11. Bigham M, Ponnampalam A. Neutralization positive but apparent false-positive hepatitis B surface antigen in a blood donor following influenza vaccination. Transfus Apher Sci 2014;50:92-4. 